\title{
Seasonal dynamics of bacterial growth efficiencies in relation to phytoplankton in the southern North Sea
}

\author{
Thomas Reinthaler*, Gerhard J. Herndl \\ Department of Biological Oceanography, Royal Netherlands Institute for Sea Research (NIOZ), PO Box 59, \\ 1790 AB Den Burg, Texel, The Netherlands
}

\begin{abstract}
The main function of heterotrophic bacterioplankton in marine carbon cycling is the conversion of dissolved organic carbon (DOC) into biomass and $\mathrm{CO}_{2}$. The relative importance of bacterial biomass production (BP) versus respiration (BR) is expressed by the bacterial growth efficiency $(B G E=B P /(B P+B R) \times 100)$. Studies on the dynamics of the BGE of bacterioplankton growing on natural DOC covering entire seasonal cycles are scarce. We measured BP and BR over a seasonal cycle in the southern North Sea at a total of 150 stations to determine seasonal variability in BGE. While BP varied over 1 order of magnitude over the seasonal cycle, BR varied only 2-fold. Cell-specific BP was related to primary production while BR was not. Mean BGE increased from $6 \pm 3 \%$ in the winter to $25 \pm 9 \%$ in the spring and summer. Depth-integrated BR was fairly stable over the seasonal cycle, averaging $57 \%$ of the particulate primary production. Based on the bacterioplankton respiration and the mean annual BGE of $20 \%$, bacterioplankton organic carbon demand amounts to $\sim 70 \%$ of the particulate primary production in the southern North Sea, suggesting that autochthonous organic matter production is sufficient to fuel bacterioplankton carbon demand.
\end{abstract}

KEY WORDS: Bacterioplankton · Bacterial production · Bacterial respiration · Bacterial growth efficiency $\cdot$ Primary production $\cdot$ North Sea

Resale or republication not permitted without written consent of the publisher

\section{INTRODUCTION}

Bacterioplankton represent the largest living biomass in the world's ocean (Whitman et al. 1998). Their main ecological function is to sequester the dissolved organic carbon (DOC) pool by incorporating a fraction of it into biomass and remineralizing the major fraction of DOC to $\mathrm{CO}_{2}$. Depending on the trophic state of the environment, bacterioplankton contribute between 12 and $>50 \%$ to total community respiration (Robinson et al. 1999, 2002b, Søndergaard et al. 2000).

Whether high remineralization rates of the prokaryotic community render the vast open-ocean into a net heterotrophic system is currently under debate (Duarte \& Agusti 1998, Williams 1998, Del Giorgio \& Duarte 2002, Hansell et al. 2004). While bacterial production (BP) is routinely measured in marine ecosystem studies, bacterial respiration (BR) has only recently received adequate attention. Determining BR rates, however, is as important as $\mathrm{BP}$ to estimate the bacterial growth efficiency $(\mathrm{BGE}=\mathrm{BP} /(\mathrm{BP}+\mathrm{BR}) \times$ $100)$ and the bacterial carbon demand. Reported BGEs span over a large range from $<1$ to $80 \%$. The underlying reasons for this large variation are basically unknown (Del Giorgio \& Cole 2000). Jahnke \& Craven (1995) suggested that the variability in the reported BGEs is due to the limited data set on respiration and concomitantly performed production measurements. Del Giorgio et al. (1997) argued that BGEs should range from $<10$ to $25 \%$ in most marine surface systems. Attempts to derive respiration rates from BP measurements are problematic because the correlation between BP and BR is usually weak (Del Giorgio \& Cole 1998). Rivkin \& Legendre (2001) found a significant relationship between BGEs and temperature using a data set across a large temperature 
range; this makes it difficult to apply their model to specific locations with smaller temperature fluctuations (Robinson et al. 2002a).

Shelf seas such as the North Sea cover only around $7 \%$ of the global ocean surface but contribute $\sim 30 \%$ to the oceanic primary production (Gattuso et al. 1998). Most studies on BP and BR are single surveys and surprisingly few marine studies have been performed over a seasonal cycle (Sherry et al. 1999, Lemme et al. 2002).

In this study, we measured BP, BR and primary production during 6 cruises covering a full seasonal cycle in the non-stratified southern North Sea occupying a total of 150 stations. The ultimate aim of the study was to determine the seasonal relationship between $\mathrm{BP}$ and $\mathrm{BR}$ and to relate the BGE dynamics to primary production and other physico-chemical variables.

\section{MATERIALS AND METHODS}

Study site. The study was carried out during 7 cruises aboard the RV 'Pelagia' in the unstratified waters of the southern North Sea (Fig. 1), occupying at total of 150 stations between July 2000 and August 2002. The mean depth of the southern North Sea is around $30 \mathrm{~m}$ and strong tidal currents and relatively high turbidity are common (Otto \& Zimmermann 1990).

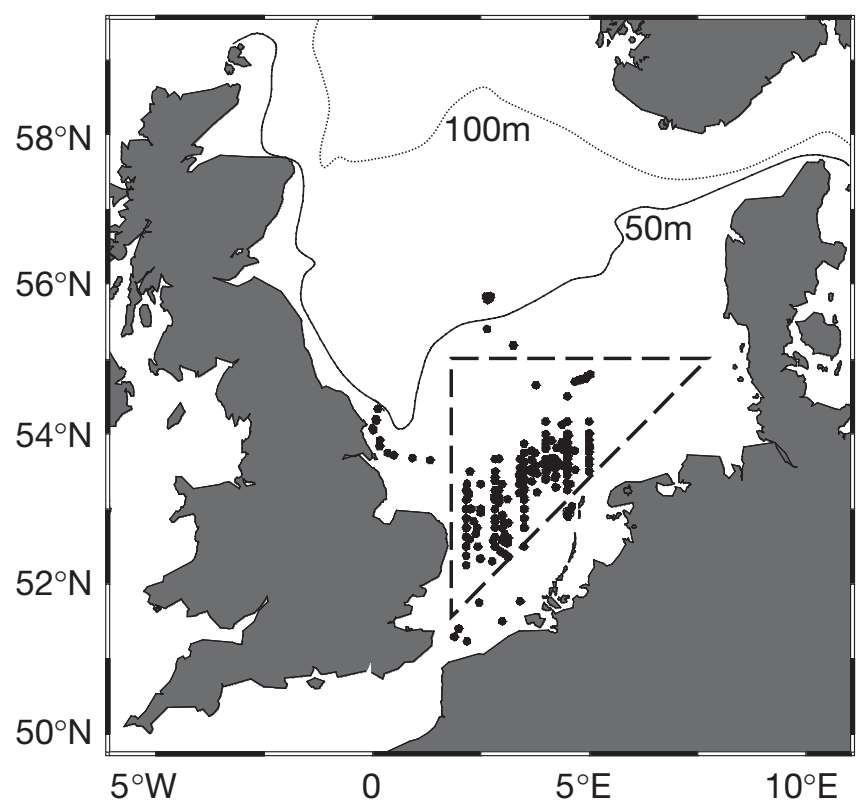

Fig. 1. Study area. Individual stations (•) occupied during the 7 cruises; only those stations enclosed by the dashed triangle were considered in the present analysis. Continuous and dotted lines mark 50 and $100 \mathrm{~m}$ isolines, respectively
Sample preparation for assessing bacterial parameters. For the parameters measured in unfiltered seawater, samples were taken at 5 and $15 \mathrm{~m}$ depth as well as $5 \mathrm{~m}$ above the bottom with $10 \mathrm{l}$ NOEX bottles mounted on a CTD rosette. Part of the water collected was drawn under gentle vacuum $(<-200 \mathrm{mbar})$ and filtered through $0.8 \mu \mathrm{m}$ polycarbonate filters (Millipore ATTP; $47 \mathrm{~mm}$ diameter) to remove most of the nonbacterial particles. To avoid clogging, filters were changed as soon as the flow rate decreased to approximately half the initial rate. Subsequently, the $0.8 \mu \mathrm{m}$ filtrate was used for bacterial production (BP) and respiration (BR) measurements and for bacterial abundance determination. Bacterial abundance and BP were also determined in unfiltered seawater. All sample handling was performed at in situ temperature $\left( \pm 2^{\circ} \mathrm{C}\right)$. Hydrographic properties of the study area are described in detail elsewhere (Baars et al. 2003). Additionally, samples were collected for chlorophyll a (chl a), phytoplankton production and dissolved organic carbon (DOC) as described below.

Bacterial abundance. We fixed $5 \mathrm{ml}$ samples with $37 \%$ formaldehyde ( $4 \%$ final conc.), and subsequently determined bacterial abundance by 4', 6-diamidino-2phenylindole (DAPI) staining and epifluorescence microscopy (Porter \& Feig 1980) upon return to the laboratory within $1 \mathrm{wk}$. Since the abundance of Archaea in the coastal North Sea is generally low (Pernthaler et al. 2002), DAPI-stained cells with distinct cell boundaries were considered to be bacteria.

Bacterial production. BP for the unfiltered and $0.8 \mu \mathrm{m}$ filtered seawater was measured by ${ }^{14} \mathrm{C}$-leucine (leu) incorporation (specific activity $0.295 \mathrm{Ci} \mathrm{mmol}^{-1}$; $10 \mathrm{nmol} \mathrm{l}^{-1}$ final conc.); 2 samples and 1 blank were incubated in the dark. The blank was fixed with formaldehyde ( $4 \%$ final conc., v/v) 10 min prior to adding the tracer. After incubating the samples and the blank at in situ temperature for $60 \mathrm{~min}$, the samples were fixed with formaldehyde ( $4 \%$ final conc.), filtered onto $0.2 \mu \mathrm{m}$ nitrocellulose filters (Millipore HA; $25 \mathrm{~mm}$ diameter) and rinsed twice with $5 \mathrm{ml}$ ice-cold $5 \%$ trichloroacetic acid (Sigma Chemicals) for $5 \mathrm{~min}$. The filters were dissolved in $1 \mathrm{ml}$ ethylacetate and, after $10 \mathrm{~min}, 8 \mathrm{ml}$ scintillation cocktail (Insta-Gel Plus, Canberra Packard) was added. The radioactivity incorporated into bacterial cells was counted in a liquid scintillation counter (LKB Wallac, Model 1212). Leucine incorporated into bacterial biomass was converted to carbon production using the empirical conversion factor $0.07 \times 10^{18} \mathrm{cells} \mathrm{mol}^{-1}$ leu (Riemann et al. 1990) and assuming a bacterial carbon content of $20 \mathrm{fg} \mathrm{C}$ cell $^{-1}$ (Lee \& Fuhrman 1987). The application of this conversion factor resulted in BP estimates similar to the theoretical factor of $1.55 \mathrm{~kg} \mathrm{C} \mathrm{mol}^{-1}$ leu, assuming no isotope dilution (Simon \& Azam 1989) (data not shown). 
Bacterial respiration. Part of the $0.8 \mu \mathrm{m}$ filtrate was carefully transferred to calibrated borosilicate glass BOD bottles with a nominal volume of $120 \mathrm{ml}$ by a sipper system to avoid the formation of air bubbles. For the determination of the initial $\mathrm{O}_{2}$ concentration $\left(t_{0}\right)$, samples were fixed immediately with Winkler reagents and incubated together with the live samples in a water bath in the dark at in situ temperature $\left( \pm 1^{\circ} \mathrm{C}\right)$ for 12 to $24 \mathrm{~h}$ before the incubations were terminated $\left(t_{1}\right)$. Triplicate bottles were used for the determination of the initial and final $\mathrm{O}_{2}$ concentration. All glassware was washed with $10 \% \mathrm{HCl}$ and thoroughly rinsed with Milli-Q water prior to use. Sample handling and fixation followed the recommendations of Carrit \& Carpenter (1966). Oxygen concentrations of corresponding $t_{0}$ and $t_{1}$ bottles were measured in one run. The amount of total iodine was determined spectrophotometrically at a wavelength of $456 \mathrm{~nm}$ on a Hitachi U-1100 spectrophotometer using a $1 \mathrm{~cm}$ flowthrough cuvette at $20^{\circ} \mathrm{C}$ (Pai et al. 1993, Roland et al. 1999). To increase the sensitivity of the absorbance readings, a 4-digit voltmeter (Metex M4650) was connected to the spectrophotometer. Calibration was performed by standard additions of iodate to distilled water, resulting in an empirical coefficient of $0.54455 \mathrm{nM} \mathrm{cm}^{-1}$ (Kraay pers. comm.). The samples were withdrawn from the BOD bottles with a Teflon tube and a peristaltic pump (Gilson Minipuls) and directly fed to the flow-through cuvette of the spectrophotometer. The end of the tube was placed near the bottom of the bottles to avoid loss of volatile iodine. The spectrophotometer was zeroed against Milli-Q water. The coefficient of variation of the oxygen determinations was $<0.5 \%$. To convert oxygen consumption into carbon we used a respiratory quotient of 1 .

Chlorophyll a determination. We gently filtered 11 water samples collected from 3 depths $(5 \mathrm{~m}, 15 \mathrm{~m}$, and $5 \mathrm{~m}$ above the bottom) through $47 \mathrm{~mm}$ Whatman GF/F filters and stored these at $-60^{\circ} \mathrm{C}$ until analysis (within $4 \mathrm{wk}$ ). Chl a was extracted in $10 \mathrm{ml}$ of $90 \%$ acetone at $-20^{\circ} \mathrm{C}$ in the dark for $48 \mathrm{~h}$. Subsequently, the filters were sonicated on ice for 1 min (Branson, Model 3200) and centrifuged to remove particles. The chl a concentration in the supernatant was determined fluorometrically with a Hitachi F-2000 fluorometer (HolmHansen et al. 1965).

Primary production (PP) measurements. For particulate PP measurements, the protocol of Gieskes et al. (1979) was followed. In brief, before sunrise, seawater was collected from $5 \mathrm{~m}$ and transferred into $250 \mathrm{ml}$ polycarbonate bottles, and $10 \mu \mathrm{Ci}$ of ${ }^{14} \mathrm{C}$ bicarbonate was added to each sample. Subsequently, the samples were placed in 6 tubes of different light transmittance using neutral-density filters. The tubes were held at surface water temperature $\left( \pm 1^{\circ} \mathrm{C}\right)$ with a flow-through seawater system. Simulated light intensities ranged from 85 to $0.6 \%$ of the surface irradiance. The incubations were run for $24 h_{i}$ thereafter, the samples were filtered onto Whatman GF/F glass-fiber filters and fumed over $\mathrm{HCl}$ for $3 \mathrm{~h}$. The filters were stored at $-20^{\circ} \mathrm{C}$ and counted in an LKB Wallac liquid scintillation counter after adding $10 \mathrm{ml}$ of Instagel II (Packard Canberra). Dark incorporation of ${ }^{14} \mathrm{C}$ bicarbonate was subtracted from the incubations in the light. Combining light-attenuation measurements of the water column with the primary production measurements performed under the different light regimens allowed us to calculate integrated PP over the water column.

DOC measurement. Samples for DOC were filtered through rinsed $0.2 \mu \mathrm{m}$ polycarbonate filters and sealed in pre-combusted $\left(450^{\circ} \mathrm{C}\right.$ for $\left.4 \mathrm{~h}\right)$ glass ampoules after adding $50 \mu \mathrm{l}$ of $40 \%$ phosphoric acid. Subsequently, the samples were stored frozen at $-20^{\circ} \mathrm{C}$. DOC concentrations were determined by the high-temperature combustion method using a Shimadzu TOC-5000 analyzer (Benner \& Strom 1993). Standards were prepared with potassium hydrogen phthalate (Nacalai Tesque). Ultrapure Milli-Q blanks were run before and after the sample analysis. The blank was on average $16.3 \pm$ $6.8 \mu \mathrm{M}$, and the mean of triplicate injections was calculated for each sample. The average analytical precision of the instrument was $<3 \%$.

Calculations and statistical analysis. As no significant differences were detectable between the different stations occupied during the individual cruises, individual parameters from each cruise were pooled. To relate bacterial biomass to phytoplankton biomass, a C:chl a ratio of 30 was used (Banse 1977). Depth integration of PP, chl $a$, BP and BR was performed with the trapezoidal method. Areal PP was depth-integrated to the $1 \%$ light level while areal BP of unfiltered seawater and BR were integrated over the whole water column. Statistical analyses were done with the software package Statistica from Statsoft on logtransformed data whenever appropriate. For regressions, the ordinary least-squares (OLS) and reduced major axis (RMA) regressions were calculated. For comparison with other published empirical models OLS is presented, whereas RMA provides a better estimate of the true functional relationship (McArdle 2003 and references therein).

\section{RESULTS}

\section{Total versus $0.8 \mu \mathrm{m}$ filtered bacterial abundance and BP}

Bacterial abundance and BP obtained for the $0.8 \mu \mathrm{m}$ fraction closely correlated with the abundance and 
production in unfiltered seawater. However, filtration through $0.8 \mu \mathrm{m}$ filters to exclude non-bacterial particles from the BR measurements reduced BP by $40 \pm$ $34 \%$ compared to the raw seawater, except in July, when BP in the $0.8 \mu \mathrm{m}$ filtered fraction and unfiltered seawater was equal. With increasing abundance and production in the unfiltered seawater, the percentage of bacterial abundance and BP recovered in the $0.8 \mu \mathrm{m}$ fraction decreased. The loss of cells due to filtration did not change significantly between different months and bacterial abundance recovered in the $0.8 \mu \mathrm{m}$ fraction was $63 \pm 21 \%$ of that in the unfiltered seawater. We used the optical backscatter readings from the CTD to estimate the relative particle load of suspended matter in the water column. From April to August, turbidity was relatively constant and sharply increased in the fall. Total bacterial abundance was not correlated with turbidity, but BP measured in unfiltered seawater showed a weak negative correlation with increasing particle load (Spearman rank correlation: $\mathrm{r}=-0.45$; $\mathrm{p}<$ $0.05 ; \mathrm{N}=108$; data not shown). Below, $\mathrm{BP}$ is referred to as the production measured in $0.8 \mu \mathrm{m}$ filtered seawater unless otherwise noted.

\section{Relations between bacterioplankton abundance, BP and BR}

Bacterial abundance of $0.8 \mu \mathrm{m}$ filtered samples increased from $0.66 \times 10^{6}$ cells $\mathrm{ml}^{-1}$ in April to $1.67 \times$ $10^{6}$ cells $\mathrm{ml}^{-1}$ in August and declined again toward winter (Fig. 2). BP and BR were significantly correlated (Fig. 3, Table 1). BP and temperature explained $61 \%$ of the variation in $\mathrm{BR}$ by multiple regression analysis, while BP alone explained only $45 \%$ of the BR (Table 1 ). In contrast, BP could not be predicted reliably from BR and temperature (Table 1).

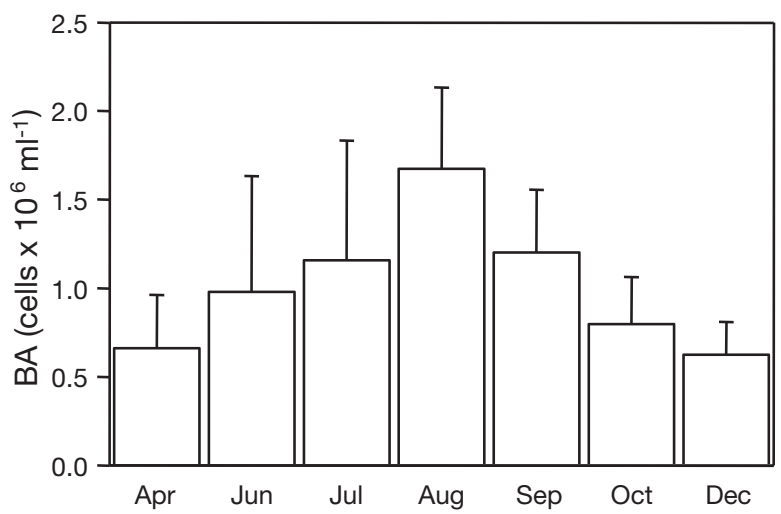

Fig. 2. Dynamics of bacterioplankton abundance (BA) in the southern North Sea $(0.8 \mu \mathrm{m}$ pre-filtered). Data are averages per cruise, error bars: standard deviations of the mean; $\mathrm{N}=11$ to 28 for the different months

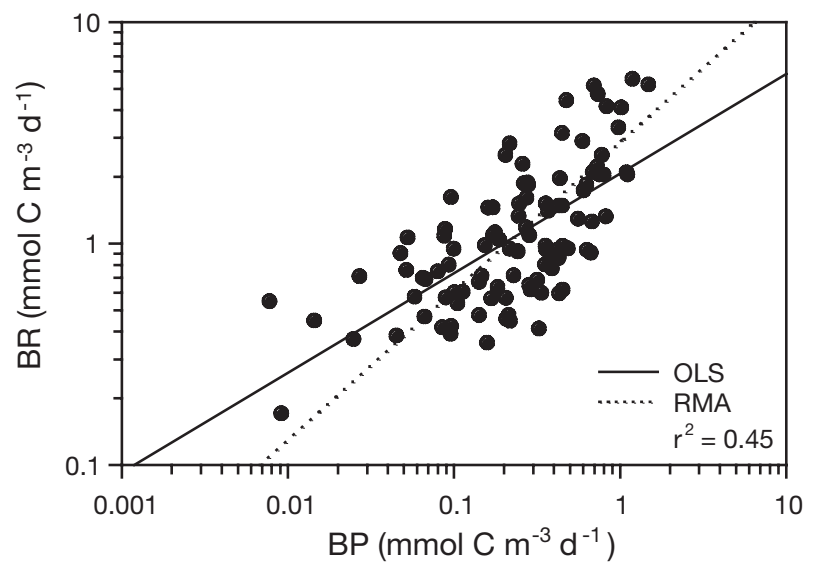

Fig. 3. Bacterial respiration (BR) as a function of bacterial production (BP) for $0.8 \mu \mathrm{m}$ filtered seawater. Ordinary leastsquares model $\left(\mathrm{OLS} ; \mathrm{r}^{2}=0.45\right)$ and reduced major-axis model $\left(\mathrm{RMA}_{i} \mathrm{r}^{2}=0.45\right)$ are fitted to data. Model statistics in Table 1

Cell-specific BP declined steadily from $0.6 \mathrm{fmol} \mathrm{C}$ cell ${ }^{-1} \mathrm{~d}^{-1}$ in April to $0.06 \mathrm{fmol} \mathrm{C}$ cell ${ }^{-1} \mathrm{~d}^{-1}$ in December Cell-specific BR was fairly constant and varied only between 1 and 2 fmol C cell ${ }^{-1} \mathrm{~d}^{-1}$ (mean: $1.4 \pm 0.71 \mathrm{fmol}$ C cell ${ }^{-1} \mathrm{~d}^{-1}$ ) with a peak of $2.1 \mathrm{fmol} \mathrm{C}$ cell $^{-1} \mathrm{~d}^{-1}$ in August (data not shown).

\section{Chlorophyll $a$ and particulate primary production}

Depth-integrated chl a concentrations were highest in April, with $96.1 \pm 78.8 \mathrm{mg}$ chl a m${ }^{-2}$, and declined

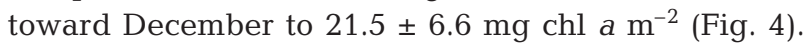
Particulate PP followed roughly the pattern of chl a (Fig. 4). The overall range of depth-integrated PP varied between 1.5 and $244.5 \mathrm{mmol} \mathrm{C} \mathrm{m}{ }^{-2} \mathrm{~d}^{-1}$ over all the stations, with an annual average of $62.0 \pm 59.8 \mathrm{mmol} C$ $\mathrm{m}^{-2} \mathrm{~d}^{-1}(\mathrm{~N}=59)$. Particulate PP was highest in April and July, with 133 and $143 \mathrm{mmol} \mathrm{C} \mathrm{m} \mathrm{d}^{-2}$, respectively, and lowest in December with an average of $5 \mathrm{mmol} \mathrm{C} \mathrm{m}^{2} \mathrm{~d}^{-1}$ (Fig. 4).

\section{Relation between phytoplankton and bacterial biomass and activity}

Over the seasonal cycle, depth-integrated total bacterial biomass (BB) was similar to depth-integrated phytoplankton biomass (PB), indicated by a BB:PB ratio of $\sim 1$ (data not shown). However, in April and June, algal biomass dominated over bacterial biomass, whereas bacterial biomass was almost twice as high as phytoplankton biomass in August. During the remaining months, the ratio of total bacterial biomass versus phytoplankton biomass was not different from 1 (Stu- 
Table 1. Regression statistics for volumetric and depth-integrated relationships of bacterial production (BP), bacterial respiration $(\mathrm{BR})$, primary production (PP) and temperature $(T)$. All variables were $\log _{10}$-transformed except for temperature. Reduced major axis (RMA) is more appropriate than ordinary least-squares (OLS) when $x$ is measured with error (McArdle 2003). A conversion factor (CF) must be used when converting log-transformed to arithmetic scale (Sprugel 1983). Volumetric units of BP and BR in mmol $\mathrm{C} \mathrm{m}^{-3} \mathrm{~d}^{-1}$, depth-integrated units in mmol C m${ }^{-2} \mathrm{~d}^{-1}$ and $T$ in ${ }^{\circ} \mathrm{C}$. Regressions follow form $\log y=\log b_{0}+x_{1} \log b_{1}\left(+x_{2} b_{2}\right)$; SE: standard error; SEE: standard error of estimate used to calculate CF; 95\% CI: upper and lower (95\%) confidence limit of estimated parameters; $\mathrm{r}^{2}$ : coefficient of determination; p: significance level; $\mathrm{N}$ : number of measurements; ${ }^{*}$ not significant

\begin{tabular}{|c|c|c|c|c|c|c|c|c|c|c|c|c|c|c|}
\hline \multirow[t]{2}{*}{ Model } & \multirow[t]{2}{*}{$y \quad x_{1}$} & \multirow[t]{2}{*}{$x_{2}$} & \multirow[t]{2}{*}{$b_{0} \pm \mathrm{SE}$} & \multirow[t]{2}{*}{$b_{1} \pm \mathrm{SE}$} & \multirow[t]{2}{*}{$b_{2} \pm \mathrm{SE}$} & \multicolumn{4}{|c|}{$95 \% \mathrm{CI}$} & \multirow[t]{2}{*}{$\mathrm{r}^{2}$} & \multirow[t]{2}{*}{$\mathrm{p}$} & \multirow[t]{2}{*}{ SEE } & \multirow[t]{2}{*}{$\mathrm{CF}$} & \multirow[t]{2}{*}{$\mathrm{N}$} \\
\hline & & & & & & & $b_{0}$ & $b$ & & & & & & \\
\hline \multicolumn{15}{|c|}{ Volumetric relationships } \\
\hline OLS & BR BP & & $0.32 \pm 0.04$ & $0.45 \pm 0.05$ & & 0.24 & 0.39 & 0.35 & 0.55 & 0.45 & $<0.001$ & 0.23 & 1.15 & 102 \\
\hline RMA & BR BP & & $0.46 \pm 0.04$ & $0.67 \pm 0.05$ & & 0.38 & -0.54 & 0.57 & 0.77 & 0.45 & & & & 102 \\
\hline OLS & BR BP & $T$ & $-0.32 \pm 0.11$ & $0.32 \pm 0.05$ & $0.04 \pm 0.01$ & & & & & 0.61 & $<0.001$ & 0.19 & & 102 \\
\hline OLS & BP BR & $T^{*}$ & $-0.70 \pm 0.18$ & $0.98 \pm 0.15$ & $0.002 \pm 0.01$ & & & & & 0.45 & $<0.001$ & 0.34 & & 102 \\
\hline \multicolumn{15}{|c|}{ Depth-integrated relationships } \\
\hline OLS & $\mathrm{BP}$ PP & & $-0.24 \pm 0.16$ & $0.66 \pm 0.09$ & & -0.56 & 0.09 & 0.48 & 0.85 & 0.50 & $<0.001$ & 0.35 & 1.38 & 55 \\
\hline RMA & BP PP & & $-0.70 \pm 0.16$ & $0.94 \pm 0.09$ & & -1.03 & -0.38 & 0.76 & 1.12 & 0.50 & & & & 55 \\
\hline OLS & BR PP & & $1.29 \pm 0.12$ & $0.18 \pm 0.07$ & & 1.04 & 1.54 & 0.04 & 0.33 & 0.15 & $<0.01$ & 0.23 & 1.16 & 39 \\
\hline RMA & BR PP & & $0.82 \pm 0.12$ & $0.48 \pm 0.07$ & & 0.57 & 1.07 & 0.33 & 0.62 & 0.15 & & & & 39 \\
\hline
\end{tabular}

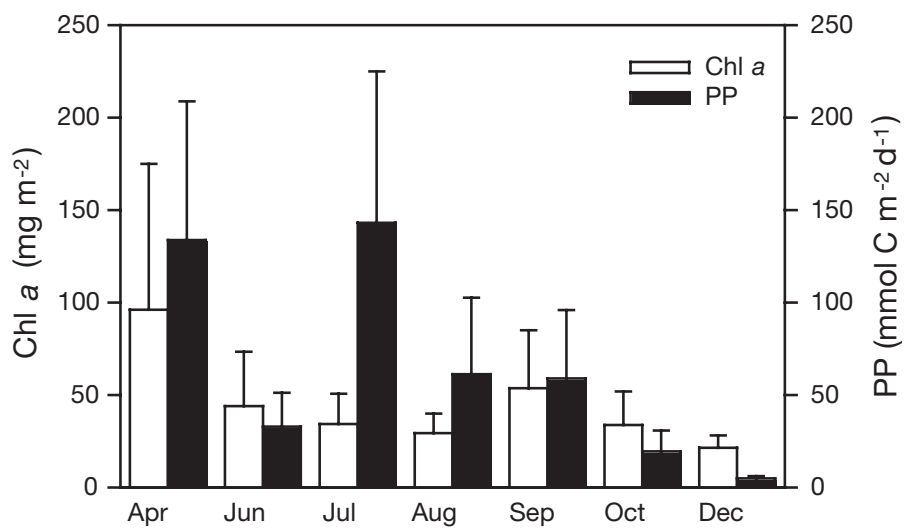

Fig. 4. Monthly averages (+SD) of depth-integrated chlorophyll $a(\mathrm{chl}$ a) and primary production (PP) measured in the southern North Sea. N $=4$ to 21 for PP and 11 to 31 for chl a for the different months

dent's $t$-test for single means; $\mathrm{p}<0.001$ ) (Fig. 5). Depthintegrated BP in unfiltered seawater averaged over the different months ranged from 1 to $26 \mathrm{mmol} \mathrm{C} \mathrm{m}^{-2} \mathrm{~d}^{-1}$. Thus, while particulate PP varied over 2 orders of magnitude, total BP was much less variable (Fig. 6a). Total $\mathrm{BP}$ as a percentage of particulate PP was highest after the bloom period in June and August, amounting for $49 \%$ of particulate PP. Over the annual cycle, total BP amounted to $16 \pm 9 \%$ of PP. BR did not exhibit any particular trend with depth in the well-mixed study area (data not shown). As for BP, BR was much less variable than phytoplankton production. Depth-integrated PP explained only about $15 \%$ of the variation in depthintegrated BR (Fig. 6b, Table 1). About $40 \%$ of the depth-integrated BR measurements were higher than

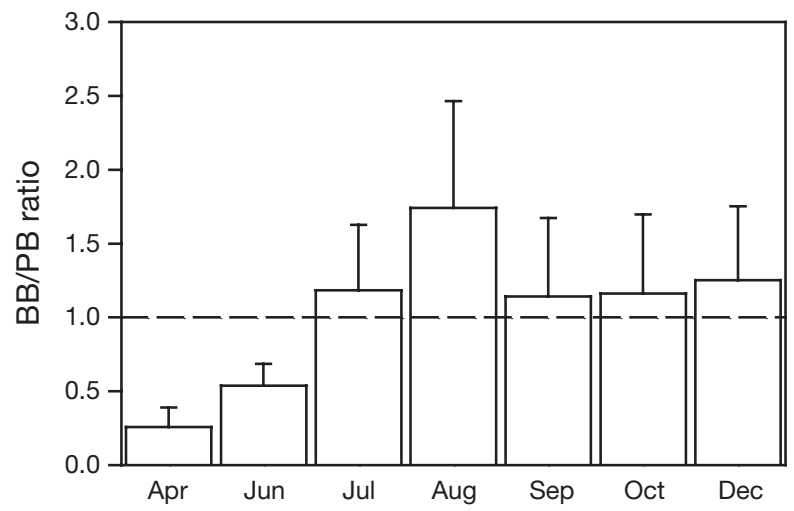

Fig. 5. Monthly mean (+SD) ratio of depth-integrated total bacterial biomass (BB) and depth-integrated phytoplankton biomass (PB). Dashed line indicates unity

the areal PP estimates. On a volumetric basis, cell-specific BP of the $0.8 \mu \mathrm{m}$ filtered fraction significantly correlated with particulate PP (Spearman rank correlation: $\mathrm{r}=0.50 ; \mathrm{p}<0.05 ; \mathrm{N}=54$ ), while cell-specific $\mathrm{BR}$ was not related to particulate PP (Fig. 7).

\section{DISCUSSION}

Generally, the southern North Sea is a highly dynamic system with strong tidal forces and a permanently well-mixed water column (Postma \& Zijlstra 1988). This probably led to the low spatial variability in phyto- and bacterioplankton biomass and activity we recorded. 

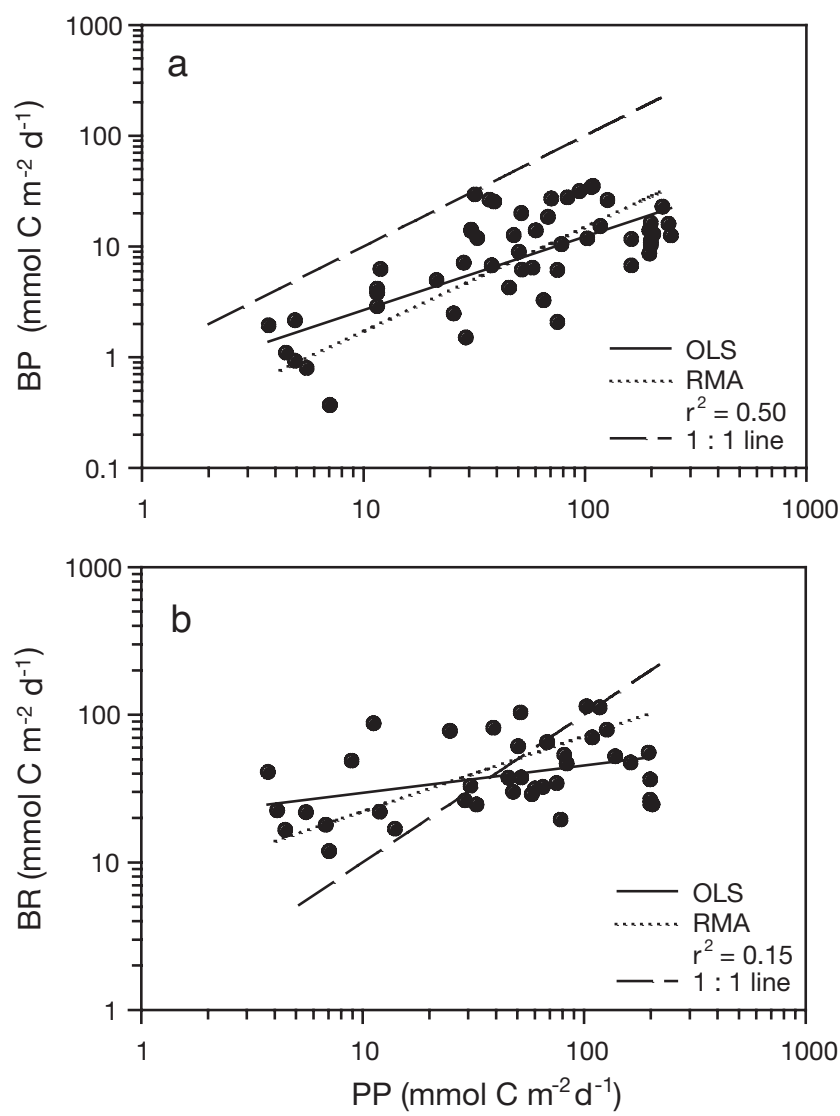

Fig. 6. (a) Depth-integrated bacterial production (BP) of unfiltered seawater and (b) depth-integrated bacterial respiration (BR) as a function of primary production (PP). Ordinary least-squares model (OLS) and reduced major-axis model (RMA) are fitted to data. 1:1 line: unity of parameters. Model statistics in Table 1

It is well known that bottle confinement, such as in BOD bottles, can bias bacterioplankton respiration estimates. An increase in bacterial abundance and community shifts during the course of incubations has been reported by several authors (Pomeroy et al. 1994, Gattuso et al. 2002). However, Williams (1981) found that despite an increase in bacterial abundance during the incubation, the respiration rate is usually linear over incubation times up to $48 \mathrm{~h}$. In our study, the average bacterial turnover rate was $0.2 \pm 0.3 \mathrm{~d}^{-1}$, and most of our incubations for respiration measurements were between 12 and $18 \mathrm{~h}$ and never longer than $24 \mathrm{~h}$. Thus, it is unlikely that bacterial abundance increased substantially during our incubations, and consequently shifts in the community composition should also be minimal. Moreover, our regression of BR on BP (Fig. 3) was very similar to that obtained by Del Giorgio \& Cole (1998), further indicating that BR in the southern North Sea is in the range of published respiration rates.

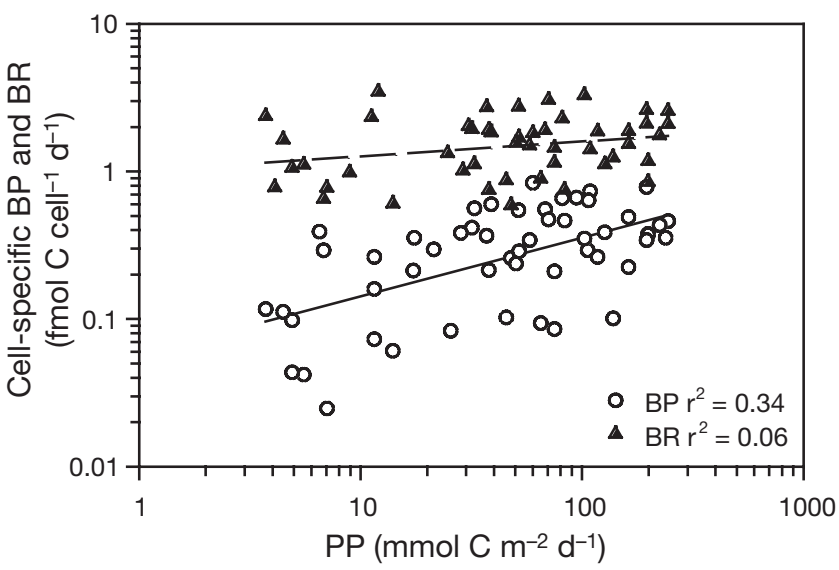

Fig. 7. Cell-specific bacterial production (BP) and respiration (BR) for $0.8 \mu \mathrm{m}$-filtered seawater as a function of particulate primary production (PP)

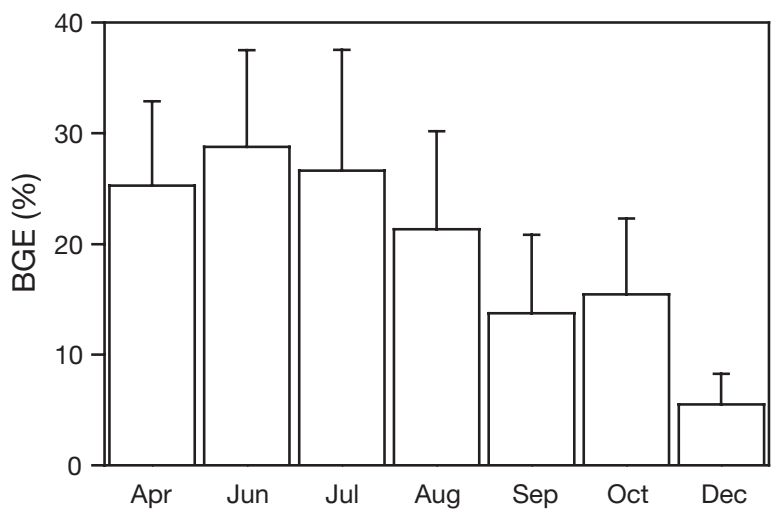

Fig. 8. Seasonal dynamics of bacterial growth efficiency $(\mathrm{BGE})$ calculated as $\mathrm{BGE}=\mathrm{BP} /(\mathrm{BP}+\mathrm{BR}) \times 100$ from April to December. Means $(+\mathrm{SD}) ; \mathrm{N}=9$ to 21 estimates for the different months

Determining BGE depends on the choice of the conversion factor used in BP estimates and on the respiratory quotient $(\mathrm{RQ})$ used. While $\mathrm{RQ}$ values are assumed to center around 1 and are considered a minor source of error (Del Giorgio \& Cole 1998), conversion factors for BP generally vary over a much larger range (Simon \& Azam 1989, Riemann et al. 1990, Ducklow et al. 1992, Kirchman 1992). We scaled the bacterial production measurements with a conversion factor typical for coastal systems (Riemann et al. 1990); however, choosing a higher conversion factor of (e.g.) $3.1 \mathrm{~kg} \mathrm{C} \mathrm{mol}^{-1}$ leu (Simon \& Azam 1989) would increase our BGEs 1.7 times. We found a clear seasonal pattern in BGE, with a median value of $25 \%$ in the spring and summer (mean $25 \pm 9 \% ; \mathrm{N}=60$ ), decreasing to a median BGE of $14 \%$ in the fall (mean $15 \pm 7 \% ; \mathrm{N}=33$ ) and $5 \%$ in the winter (mean $6 \pm 3 \% ; \mathrm{N}=9$ ) (Fig. 8). The annual 
median BGE in the southern North Sea was $19 \%$ (mean $20 \pm 11 \% ; \mathrm{N}=102$ ), which is similar to the overall BGE of $20 \%$ obtained by Del Giorgio \& Cole (2000) compiling available information from marine surface waters and Carlson et al. (1999) from a similar highlatitude system.

The seasonality in BGE is mainly driven by the changes in BP, which vary 6-fold from spring to winter. BR was generally rather uniform over the seasonal cycles, although there was a slight increase in cellspecific BR toward the warmer summer months. A peak in respiration coinciding with the annual temperature maximum was reported previously (Smith \& Kemp 1995 and references therein), but in our study this increase was too small to significantly influence the pattern of BGE. While Sherry et al. (1999) found that the seasonal dynamics in BGE were influenced more by bacterial respiration rather than production along an E-W transect in the NE Pacific, our finding is in agreement with that of Del Giorgio \& Cole (2000), who concluded that BP was mainly determining BGEs.

Reports on temperature-dependence of bacterioplankton metabolism are contradictory. White et al. (1991) used a multiple regression including bacterial abundance and temperature to explain the variability in BP. Pomeroy \& Wiebe (2001) argued that temperature and substrate availability are both limiting factors for heterotrophic bacteria, while Del Giorgio \& Cole (1998) concluded that temperature was not an important factor controlling bacterioplankton activity. Over the temperature range of our study $\left(9\right.$ to $18^{\circ} \mathrm{C}$; Table 2$)$, temperature explained only around $32 \%$ of the variability in BP. Thus, in the southern North Sea temperature does not explain the seasonality in $\mathrm{BP}$, and the model from Rivkin \& Legendre (2001) to derive BGE from BP and temperature cannot be applied here, as they used a much larger temperature range. In a study in the northern North Sea, Robinson et al. (2002b) calculated BR from the model of Rivkin \& Legendre (2001), and the resulting estimate grossly underestimated the bacterial contribution to total respiration compared to the model of Del Giorgio \& Cole (1998)

Table 2. Monthly averages of mixed-layer depth (m), salinity $(S, \mathrm{PSU})$, temperature $\left(T,{ }^{\circ} \mathrm{C}\right)$ and DOC concentration $(\mu \mathrm{M})$

\begin{tabular}{|llcccc|}
\hline Month & Depth & $S$ & $T$ & DOC & N \\
\hline Apr & $40 \pm 20$ & $34.01 \pm 1.19$ & $8.8 \pm 0.8$ & $72.7 \pm 20.5$ & 32 \\
Jun & $29 \pm 7$ & $34.12 \pm 0.29$ & $12.2 \pm 0.3$ & $139.8 \pm 34.7$ & 17 \\
Jul & $28 \pm 6$ & $34.63 \pm 0.28$ & $14.9 \pm 0.2$ & $86.5 \pm 9.6$ & 20 \\
Aug & $33 \pm 7$ & $34.28 \pm 0.30$ & $18.4 \pm 0.5$ & $265.3 \pm 89.0$ & 23 \\
Sep & $28 \pm 6$ & $34.31 \pm 0.21$ & $16.6 \pm 1.0$ & $87.1 \pm 19.9$ & 17 \\
Oct & $31 \pm 8$ & $34.48 \pm 0.23$ & $13.1 \pm 1.2$ & $107.6 \pm 19.2$ & 31 \\
Dec & $30 \pm 8$ & $34.55 \pm 0.48$ & $10.3 \pm 0.9$ & $152.2 \pm 43.5$ & 11 \\
\hline
\end{tabular}

which gave more a reasonable value of $\sim 60 \%$ of total respiration.

Other factors causing seasonal fluctuations in BP are changes in the concentrations of readily utilizable dissolved organic matter (DOM) due to variable extracellular release of phytoplankton, grazing activity and/or allochthonous input of organic material via rivers. In our study, phytoplankton biomass (measured as chl a) was not related to bacterial abundance; however, a positive relationship was found between PP and specific BP (Fig. 7).

The lowest mean DOC concentrations of around $73 \mu \mathrm{M}$ were measured in the spring and DOC peaked in August with an average of $265 \mu \mathrm{M}$, but no clear seasonal pattern was apparent (Table 2). Søndergaard \& Middelboe (1995) estimated that in marine environments around $19 \%$ of the bulk DOC is labile and used by prokaryotes within 1 and 2 wk. The more labile components of the DOC pool are directly or indirectly fueled by the release from phytoplankton, and this DOM is remineralized within hours (Fuhrman 1987, Rich et al. 1997). Natural DOC consists of a continuum of size classes of differing diagenetic state (Amon \& Benner 1996), which makes it difficult to directly relate bulk DOC measurements to BP and growth. As a measure of the availability of labile DOC we used the ratio of BP to bulk DOC (Obernosterer et al. 1999). In the spring and summer, relatively more labile DOC is available, as indicated by a higher ratio between BP and bulk DOC concentration than in the winter (Fig. 9a). The ratio of BP to DOC, as a function of phytoplankton production, indicates that the increase in the relative availability of DOC is related to increased pp (Fig. 9b). Therefore, we conclude that the BP in the southern North Sea is mainly coupled to the seasonal dynamics in primary production and that BGE is directly linked to the bioavailability of DOC and indirectly to PP (Fig. 9c). While such a conclusion would be expected for open-ocean systems, for a shelf sea such as the North Sea this conclusion is not so obvious, considering the large input of terrigenous material via rivers.

To assess the relative importance of autotrophic versus heterotrophic processes, the ratio of phytoplankton production to bacterial carbon demand (BCD) based on the total BP measurements was calculated. We used the depth-integrated values of PP and BR because, as Williams (1998) pointed out, PP should be considered on an areal basis to account for the solar radiation dependency of PP. A considerable part of the phytoplankton production may be lost to the dissolved phase through extracellular release of DOC (Kaltenböck \& Herndl 1992). Thus our PP measurements are likely to underestimate actual total phytoplankton production (Teira et al. 2001). The PP:BCD ratio was significantly 
higher than 1 in April and July while in August and December the southern North Sea was heterotrophic (Student's $t$-test for single means; $\mathrm{p}<0.001$ ) (Fig. 10). The remaining months exhibited roughly a metabolic balance, i.e. the ratio was not significantly different
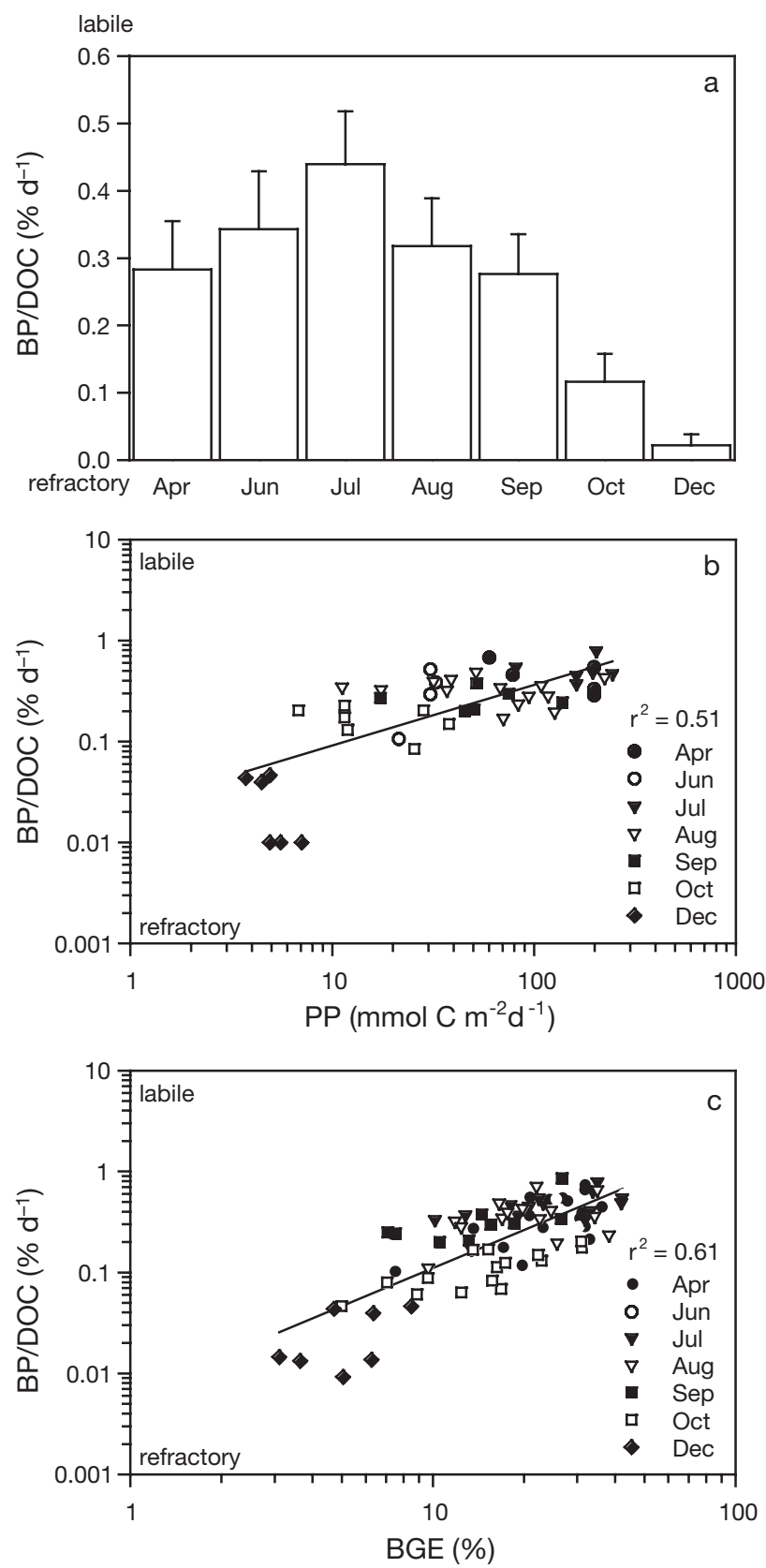

Fig. 9. Total bacterial production $\left(\mathrm{BP} ; \mathrm{mmol} \mathrm{C} \mathrm{m} \mathrm{m}^{-3} \mathrm{~d}^{-1}\right)$ normalized to dissolved organic carbon ( $\mathrm{DOC}_{i} \mathrm{mmol} \mathrm{C} \mathrm{m}{ }^{-3}$ ) to indicate relative DOC availability $(\mathrm{BP} / \mathrm{DOC} \times 100)$. (a) Distribution of DOC available over the seasonal cycle, showing ratio of monthly averages; means (+SD). (b) Relation of depthintegrated primary production and available DOC. (c) Dependence of bacterial growth efficiency (BGE) on DOC availability

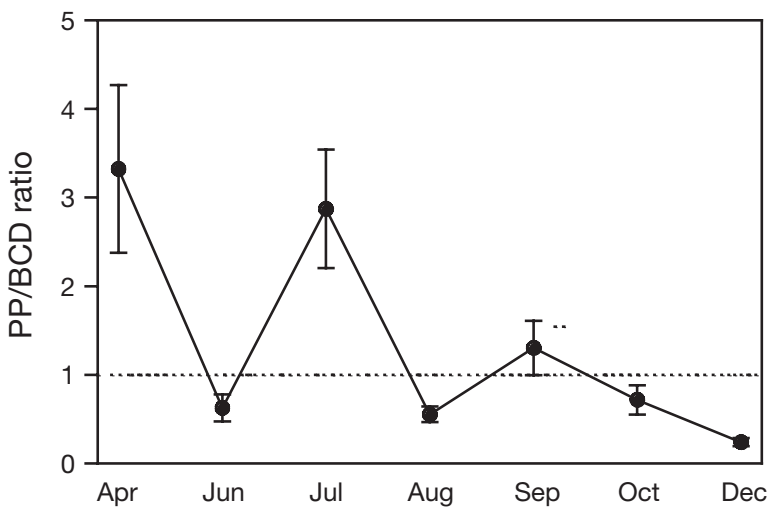

Fig. 10. Ratio between particulate primary production (PP) and total bacterial carbon demand (BCD) over seasonal cycle. Means $( \pm \mathrm{SD})$ of 10 estimates

from 1 (Fig. 10). This pattern generally agrees with a recent study of Thomas et al. (2004), who measured fluxes of $\mathrm{CO}_{2}$ in the North Sea on a seasonal scale. They found that the southern part was slightly heterotrophic throughout the year, except in spring when $\mathrm{CO}_{2}$ uptake from the atmosphere prevailed.

Recently, evidence has been presented that openocean systems are slightly heterotrophic (Del Giorgio et al. 1997, Duarte \& Agusti 1998, Williams 1998). In marginal seas such as the North Sea, short-term trophic imbalances might be compensated by terrestrial input via rivers and terrestrial runoff. In the southern North Sea, the rivers Humber, Thames and the Rhine provide considerable amounts of DOM (A. V. Borges et al. unpubl.); thus, potentially, even long periods of net system heterotrophy would be possible. Decreasing PP toward the winter was paralleled by decreasing BGE. However, in the spring and early summer the supply of autochthonous DOM supports a relatively high BGE until most of the labile DOM is depleted in August.

In summary, we have shown that seasonality in BP is mainly responsible for the dynamics in BGE which, in turn, is influenced by the bioavailability of DOC. Remineralization of organic carbon is the main function of prokaryotes in carbon cycling and, as such, is relatively stable over the annual cycle.

Acknowledgements. We thank J. Hegeman, S. Oosterhuis, A. Noordeloos and S. Gonzalez for the primary production, chlorophyll $a$ and DOC data. Special thanks to G. van Noort and C. Winter for help with analysis of the bacterial abundance data and to $\mathrm{M}$. Baars for his excellent job as chief scientist during the Bloom and Plume project and to the captain and crew of the RV 'Pelagia'. This work was supported by the Dutch Science Foundation (NWO-ALW) project 811.33.002 and the European Commission through the COMET project to G.J.H. This work is in partial fulfillment of the requirements for a PhD degree from the University of Groningen by T.R. 


\section{LITERATURE CITED}

Amon RMW, Benner R (1996) Bacterial utilization of different size classes of dissolved organic matter. Limnol Oceanogr 41:41-51

Baars MA, Oosterhuis S, Kuipers B (2003) Plume and bloom: water mass patterns and nutrient dynamics in the central part of the southern Bight. Annual report 2002, Royal Netherlands Institute for Sea Research, Texel

Banse K (1977) Determining the carbon-to-chlorophyll ratio of natural phytoplankton. Mar Biol 41:199-212

Benner R, Strom M (1993) A critical evaluation of the analytical blank associated with DOC measurements by hightemperature catalytic oxidation. Mar Chem 41:153-160

Carlson CA, Bates NR, Ducklow HW, Hansell DA (1999) Estimation of bacterial respiration and growth efficiency in the Ross Sea, Antarctica. Aquat Microb Ecol 19:229-244

Carrit DE, Carpenter JH (1966) Comparison and evaluation of currently employed modifications of the Winkler method for determining dissolved oxygen in seawater; a NASCO report. J Mar Res 24:287-318

Del Giorgio PA, Cole JJ (1998) Bacterial growth efficiency in natural aquatic systems. Annu Rev Ecol Syst 29:503-541

Del Giorgio PA, Cole JJ (2000) Bacterial energetics and growth efficiency. In: Kirchman DL (ed) Microbial ecology of the oceans. Wiley-Liss, New York, p 289-325

Del Giorgio PA, Duarte CM (2002) Respiration in the open ocean. Nature 420:379-384

Del Giorgio PA, Cole JJ, Cimberis A (1997) Respiration rates of bacteria exceed phytoplankton in unproductive aquatic systems. Nature 385:148-151

Duarte CM, Agusti S (1998) The $\mathrm{CO}_{2}$ balance of unproductive aquatic ecosystems. Science 281:234-236

Ducklow HW, Kirchman DL, Quinby HL (1992) Bacterioplankton cell growth and macromolecular synthesis in seawater cultures during the North Atlantic spring phytoplankton bloom, May, 1989. Microb Ecol 24:125-144

Fuhrman J (1987) Close coupling between release and uptake of dissolved free amino acids in seawater studied by an isotope dilution approach. Mar Ecol Prog Ser 37:45-52

Gattuso JP, Frankignoulle M, Wollast R (1998) Carbon and carbonate metabolism in coastal aquatic ecosystems. Annu Rev Ecol Syst 29:405-434

Gattuso JP, Peduzzi S, Pizay D, Tonolla M (2002) Changes in freshwater bacterial community composition during measurements of microbial and community respiration. J Plankton Res 24:1197-1206

Gieskes WWC, Kraay GW, Baars MA (1979) Current C-14 methods for measuring primary production-gross underestimates in oceanic waters. Neth J Sea Res 13:58-78

Hansell DA, Ducklow HW, Macdonald AM, Baringer MON (2004) Metabolic poise in the North Atlantic Ocean diagnosed from organic matter transports. Limnol Oceanogr 49:1084-1094

Holm-Hansen O, Lorenzen CL, Holmes RW, Strickland JDH (1965) Fluorometric determination of chlorophyll. J Cons Perm Int Explor Mer 30:3-15

Jahnke RA, Craven DB (1995) Quantifying the role of heterotrophic bacteria in the carbon cycle: a need for respiration rate measurements. Limnol Oceanogr 40:436-441

Kaltenböck E, Herndl GJ (1992) Ecology of amorphous aggregations (marine snow) in the northern Adriatic Sea. IV. Dissolved nutrients and the autotrophic community associated with marine snow. Mar Ecol Prog Ser 87:147-159

Kirchman DL (1992) Incorporation of thymidine and leucine in the subarctic Pacific: application to estimating bacterial production. Mar Ecol Prog Ser 82:301-309
Lee S, Fuhrman JA (1987) Relationships between biovolume and biomass of naturally derived marine bacterioplankton. Appl Environ Microbiol 53:1298-1303

Lemme R, Rochelle-Newall E, Van Wambeke F, Pizay MD, Rinaldi P, Gattuso JP (2002) Seasonal variation of bacterial production, respiration and growth efficiency in the open NW Mediterranean Sea. Aquat Microb Ecol 29:227-237

McArdle BH (2003) Lines, models, and errors: regression in the field. Limnol Oceanogr 48:1363-1366

Obernosterer I, Reitner B, Herndl GJ (1999) Contrasting effects of solar radiation on dissolved organic matter and its bioavailability to marine bacterioplankton. Limnol Oceanogr 44:1645-1654

Otto L, Zimmermann JTF (1990) Physical oceanography of the North Sea. Neth J Sea Res 26:163-238

Pai SC, Gong GC, Liu KK (1993) Determination of dissolved oxygen in seawater by direct spectrophotometry of total iodine. Mar Chem 41:343-351

Pernthaler A, Preston CM, Pernthaler J, DeLong EF, Amann R (2002) Comparison of fluorescently labeled oligonucleotide and polynucleotide probes for the detection of pelagic marine bacteria and archaea. Appl Environ Microbiol 68:661-667

Pomeroy LR, Wiebe WJ (2001) Temperature and substrates as interactive limiting factors for marine heterotrophic bacteria. Aquat Microb Ecol 23:187-204

Pomeroy LR, Sheldon JE, Sheldon WM (1994) Changes in bacterial numbers and leucine assimilation during estimations of the microbial respiratory rates in seawater by the precision Winkler method. Appl Environ Microbiol 60:328-332

Porter KG, Feig YS (1980) The use of DAPI for identifying and counting aquatic microflora. Limnol Oceanogr 25:943-948

Postma H, Zijlstra JJ (1988) Continental shelves, Vol 27. Elsevier, New York

Rich J, Gosselin M, Sherr EB, Sherr BF, Kirchman D (1997) High bacterial production, uptake and concentrations of dissolved organic matter in the central Arctic Ocean. Deep-Sea Res II 44:1645-1663

Riemann B, Bell RT, Jørgensen NOG (1990) Incorporation of thymidine, adenine and leucine into natural bacterial assemblages. Mar Ecol Prog Ser 65:87-94

Rivkin RB, Legendre L (2001) Biogenic carbon cycling in the upper ocean: effects of microbial respiration. Science 291: 2398-2400

Robinson C, Archer SD, Williams PJL (1999) Microbial dynamics in coastal waters of East Antarctica: plankton production and respiration. Mar Ecol Prog Ser 180:23-36

Robinson C, Serret P, Tilstone G, Teira E, Zubkov MV, Rees AP, Woodward EMS (2002a) Plankton respiration in the Eastern Atlantic Ocean. Deep-Sea Res I 49:787-813

Robinson C, Widdicombe CE, Zubkov MV, Tarran GA, Miller AEJ, Rees AP (2002b) Plankton community respiration during a coccolithophore bloom. Deep-Sea Res II 49: 2929-2950

Roland F, Caraco NF, Cole JJ, Del Giorgio PA (1999) Rapid and precise determination of dissolved oxygen by spectrophotometry: evaluation of interference from color and turbidity. Limnol Oceanogr 44:1148-1154

Sherry ND, Boyd PW, Sugimoto K, Harrison PJ (1999) Seasonal and spatial patterns of heterotrophic bacterial production, respiration, and biomass in the Subarctic NE Pacific. Deep-Sea Res II 46:2557-2578

Simon M, Azam F (1989) Protein content and protein synthesis rates of planktonic marine bacteria. Mar Ecol Prog Ser 51:201-213

Smith EM, Kemp WM (1995) Seasonal and regional variations 
in plankton community production and respiration for Chesapeake Bay. Mar Ecol Prog Ser 116:217-231

Søndergaard M, Middelboe M (1995) A cross system analysis of labile dissolved organic carbon. Mar Ecol Prog Ser 118: 283-294

Søndergaard M, Williams PJL, Cauwet G, Riemann B, Robinson C, Terzic S, Woodward EMS, Worm J (2000) Net accumulation and flux of dissolved organic carbon and dissolved organic nitrogen in marine plankton communities. Limnol Oceanogr 45:1097-1111

Sprugel DG (1983) Correcting for bias in log-transformed allometric equations. Ecology 64:209-210

Teira E, Pazo MJ, Pablo S, Emilio F (2001) Dissolved organic carbon production by microbial populations in the Atlantic Ocean. Limnol Oceanogr 46:1370-1377

Editorial responsibility: Frede Thingstad,

Bergen, Norway
Thomas H, Bozec Y, Elkalay K, de Baar HJW (2004) Enhanced open ocean storage of $\mathrm{CO}_{2}$ from shelf sea pumping. Science 304:1005-1008

White PA, Kalff J, Rasmussen JB, Gasol JM (1991) The effect of temperature and algal biomass and bacterial production and specific growth rate in freshwater and marine habitats. Microb Ecol 21:99-118

Whitman WB, Coleman DC, Wiebe WJ (1998) Prokaryotes: the unseen majority. Proc Natl Acad Sci USA 95: 6578-6583

Williams PJleB (1998) The balance of plankton respiration and photosynthesis in the open oceans. Nature 394:55-57

Williams PPJleB (1981) Microbial contributions to overall marine plankton metabolism: direct measurements of respiration. Oceanol Acta 4:359-370

Submitted: June 21, 2004; Accepted: January 10, 2005

Proofs received from author(s): March 11, 2005 